\title{
The promises and risks of probiotic Bacillus species
}

\author{
Joanna Jezewska-Frackowiak ${ }^{1 凶}$, Krystyna Seroczynska², Justyna Banaszczyk2, \\ Gabriela Jedrzejczak², Agnieszka Zylicz-Stachula' ${ }^{1}$ and Piotr M. Skowron ${ }^{1}$ \\ 'Department of Molecular Biotechnology, Faculty of Chemistry, University of Gdansk, Gdańsk, Poland; ${ }^{2}$ GRUPA INCO S.A., Warszawa, Poland
}

Supplementing the human microbiome with probiotic microorganisms is a proposed solution for civilization syndromes such as dysbiosis and gastrointestinal tract (GIT) disorders. Bimodal probiotic strains of the Bacillus genus constitute the microbiota of the human environment, and are typically found in soil, water, a number of non-dairy fermented foods, as well as in human and animal GIT. Probiotic Bacillus sp. are Gram positive rods, with the ability of sporulation to survive environmental stress and preparation conditions. In vitro models of the human stomach and human studies with probiotic Bacillus reveal the mechanisms of its life cycle and sporulation. The Bacillus sp. probiotic biofilm introduces biochemical effects such as antimicrobial and enzymatic activity, thus contributing to protection from GIT and other infections. Despite the beneficial activity of Bacillus strains belonging to the safety group 1, a number of strains can pose a substantial health risk, carrying genes for various toxins or antibiotic resistance. Commercially available Bacillus probiotic preparations include strains from the subtilis and other closely related phylogenetic clades. Those intended for oral administration in humans, often encapsulated with appropriate supporting materials, still tend to be mislabeled or poorly characterized. Bacillus sp. MALDI-TOF analysis, combined with sequencing of characteristic 16S rRNA or enzyme coding genes, may provide accurate identification. A promising future application of the probiotic Bacillus sp. might be the microflora biocontrol in the human body and the closest human environment. Environmental probiotic Bacillus species display the potential to support human microflora, however controversies regarding the safety of certain strains is a key factor in their still limited application.

Key words: Bacillus sp. for detergents, Bacillus sp. probiotic preparation, Bacillus sp. probiotic safety, Bacillus subtilis, biocontrol, human microbiome, probiotic formulations, spore formers

Received: 31 July, 2018; revised: 19 November, 2018; accepted: 22 November, 2018; available on-line: 06 December, 2018

e-mail: j.jezewska-frackowiak@ug.edu.pl

Abbreviations: EFSA, European Food Safety Authority; FDA, Food and Drug Administration; GIT, gastrointestinal tract: GRAS, Generally Recognized as Safe; LAB, lactic acid bacteria; MALDI-TOF, matrixassisted laser desorption/ionization-time of flight; SP, spore; UGT, urogenital tract; UT, urinary tract; VC, vegetative cell; WFCC, World Federation for Culture Collections

\section{HUMAN MICROBIOME IN THE CONTEXT OF MODERN LIFESTYLE}

The human organism comprises approximately 40 trillion cells (approx. $4 \times 10^{13}$ ) with 22 thousand genes, while the microflora present in the whole body and on the surface is estimated to be 100 trillion $\left(10^{14}\right)$ microbial cells, described as microbiota, with approximately 2 million metagenome microbial genes (Turnbaugh et al., 2007; Ravel et al., 2014). This overall population of microorganisms has been extensively analyzed since 2007 in the Human Microbiome project, utilizing modern sampling methods at different body locations, DNA/RNA purification techniques, advanced computational technologies with specialized software for fast DNA sequencing, as well as 16S rRNA gene sequence-based analyses, with statistical advances enabling the integration of multi data sets of microbiota colonizing the skin, mouth, esophagus, stomach, vagina, colon, and other body parts. Microbiome studies are crucial for understanding the consequences of modern lifestyle (Schnorr et al., 2016), with the substantial changes of human microflora being the side-effect of accessible antibiotic therapies, presence of antimicrobial factors in the cleaning agents and detergents for everyday cleaning routines, automated washing and dishwashing, abandoned breastfeeding and consumption of highly processed foods.

Since developed countries have greatly decreased human exposure to the microbes, pathogens, commensals, and naturally residing environmental strains, scientists are provoked to ask: aren't we too clean...? The "hygiene hypothesis” (Strachan, 1989) and „microbial deprivation hypothesis" (Bloomfield et al., 2006) state that the rapid rise of atopic, allergy, and asthma disorders (Björkstén, 1994; Björkstén et al., 1999; West et al., 2017; Abreo et al., 2018) in the last 30-40 years may be related to the above-mentioned changes in hygienic and nutritional practices, resulting in the "dysbiosis" state of an organism (Waligora-Dupriet \& Butel, 2012). Under these conditions, a growing interest in supplementing and/or supporting the natural and beneficial microflora seems to be a promising natural remedy (Quigley, 2010; WaligoraDupriet \& Butel, 2012).

\section{CONTEMPORARY DEFINITIONS AND HEALTH CLAIMS FOR PROBIOTICS}

The beginning of the history of probiotics in the scientific field is associated with the Russian microbiologist Ilya Metchnikoff (1845-1916), the author of the early 20th century work entitled "The dependence of the intestinal microbes on the food makes it possible to adopt measures to modify the flora in our bodies and to replace harmful microbes with useful microbes". Metchnikoff associated good health and exceptional longevity of inhabitant groups from Eastern Europe with their orderly consumption of fermented dairy products (Metchnikoff, 1907). According to contemporary authors Havenaar and Huis In't Veld (Havenaar \& Huis In't Veld, 
1992), a „probiotic is a mono- or mixed culture of live microorganisms which, applied to animal or man, affect beneficially the host by improving the properties of the indigenous microflora". Hence, the emphasis is put on the probiotic microorganisms' positive activity rather than on the route of their administration, extending the modes of possible application. Nevertheless, this proposed definition implies that the term „probiotic" is restricted to products that: 1) contain live microorganisms, e.g. as freeze-dried cells or in a fermented product; 2) improve human or animal health (which can include the promotion of animal growth); 3) cause an effect in the mouth or in the gastrointestinal tract (GIT, e.g. when applied in food or administered capsules, systemic application), in the upper respiratory tract (RT, applied with aerosol, local application), or in the urogenital or urinary tract (UGT or UT, capsules or globules, systemic or local application).

This broadened meaning of probiotics is particularly worth mentioning, as the frequently cited FAO/WHO report from expert consultations (Araya et al., 2001) presents a commonly used definition of probiotics as "live microorganisms which when administered in adequate amounts confer a health benefit on the host" and subsequently focuses the discussion on "live microorganisms which when consumed in adequate amounts as part of food, confer a health benefit on the host". This FAO/ WHO publication is closely related to the theme of that particular meeting, where the main focus was on the scientific background of probiotic lactic acid bacteria present exclusively in food and powdered milk.

Nevertheless, the intrinsic and crucial probiotic feature is the application of species proven to be safe for human or animal health. Many probiotic strains, including the Bifidobacterium, Lactobacillus and Bacillus genera, have been used traditionally for ages in food manufacturing processes and their long history of safe use has promoted them in contemporary biotechnological and health / food related industries. Some of these strains are described as "Generally Recognized As Safe" (GRAS), according to U.S. Food and Drug Administration. The GRAS inventory presents intended conditions of use and laboratory data necessary for the evaluation process, which are given a particular file number (GRN No). The notifier (the producer/seller/company) carries the entire responsibility of ensuring the quality and compliance with legal and regulatory requirements of a notified item. As far as the probiotic strains are concerned, the "Lactobacillus" GRAS entry covers 23 positions, spanning in time of closure from Dec. 2005 to Aug. 2018, and lists a number of strains including Lactobacillus acidophilus NP28, NP 51, La-14, L. lactis, L. casei subsp. rhamnosus GG, L. paracasei subsp. Paracasei, L. reuteri DSM 17938, L. plantarum 299v, Lp 115, L. helveticus and two Bifidobacterium strains. Their intended use is declared to be mainly as an ingredient of food products, e.g. yoghurt, dairy products (GRN 736), powdered infant formulas (GRN 231) or cereals, cheese, and dairy products (GRN 357). Interestingly, the "Bacillus" GRAS entry covers as many as 67 positions, recorded from September 1999 to June 2018. Most of these entries relate to biotechnological products, derived from different probiotic Bacillus sp. strains. The inventory covers vegetative cells, inactivated cells with thermally killed cell preparations or spore preparations, and biochemical preparations from native and recombinant Bacillus sp. strains. Genetically modified Bacillus strains carry genes for GRAS enzymes such as acetolactate decarboxylase (GRN 587), $\beta$-galactosidase (GRN 649), glucanases (GRN 592), maltohydrolase (GRN 746), phospholipase (GRN 689) or protease (GRN 564), a.o. The present state (by the end of Oct. 2018) of biochemical or biotechnological products, derived from non- modified, probiotic Bacillus species and recognized as safe under intended conditions of use, is given in Table 1.

The most important European Union legislative work to date referring to the health and nutritional properties of probiotics in food is still the FAO/WHO Report, which gives precise recommendations towards safety, labeling and characterization of probiotics (Araya et al., 2001). Interestingly, in the European Union legal framework, the probiotics are treated as food supplements or additives, and since the impact of probiotic definitions is put on health benefits, intensive legal work has been carried out to develop a system of health claims evalua-

Table 1. Probiotic Bacillus species bio-products recognized as safe in GRAS Notice Inventory*.

\begin{tabular}{|c|c|c|c|c|}
\hline \multicolumn{5}{|l|}{ Bio- products } \\
\hline Name & Source strain & Intended usage & $\begin{array}{l}\text { GRAS notification } \\
\text { file number }\end{array}$ & Date of closure \\
\hline \multicolumn{5}{|l|}{ Enzymes } \\
\hline$\beta$-glucanase & \multirow[b]{2}{*}{ Bacillus subtilis } & Production of beer and potable alcohol & 592 & 2015 \\
\hline $\begin{array}{l}\text { Polygalacturonate lyase } \\
\text { (pectate lyase) }\end{array}$ & & $\begin{array}{l}\text { Fruit and vegetable purees and concen- } \\
\text { trates }\end{array}$ & 114 & 2003 \\
\hline \multicolumn{5}{|l|}{ Vegetative cells } \\
\hline \multirow{4}{*}{ Cells } & Bacillus coagulans & Water additive for processing of bananas & $559 ; \mathrm{EC}^{* *}$ & 2015 \\
\hline & Bacillus licheniformis & Water additive for processing of bananas & 560; EC & 2015 \\
\hline & Bacillus pumilus & Water additive for processing of bananas & $561 ; \mathrm{EC}$ & 2015 \\
\hline & Bacillus subtilis & Water additive for processing of bananas & $562 ; \mathrm{EC}$ & 2015 \\
\hline \multicolumn{5}{|l|}{ Inactivated cells } \\
\hline Thermally killed cells & $\begin{array}{l}\text { Bacillus coagulans } \\
\text { GBI-30, } 6086\end{array}$ & $\begin{array}{l}\text { Liquid and powdered infant formulas/ } \\
\text { Food additive, baked goods, beverages, } \\
\text { cereals }\end{array}$ & 670,725 & 2017, 2018 \\
\hline Spores & $\begin{array}{l}\text { Bacillus coagulans } \\
\text { GBI-30, } 6086\end{array}$ & $\begin{array}{l}\text { Food additive, baked goods, beverages, } \\
\text { cereals, powdered or liquid infant formulas }\end{array}$ & $\begin{array}{l}399,526,597,601 \\
660,691\end{array}$ & $\begin{array}{l}\text { 2012, 2015, 2016, } \\
2016,2017,2017\end{array}$ \\
\hline
\end{tabular}


tion. The probiotic health benefit of an individual strain or mixed preparation must be assayed in vivo, showing a health effect in an appropriate human population. The European Food Safety Authority (EFSA) publishes scientific opinions if the subjected probiotic health claims are consistent with the Regulation on Health Claims (EC No 1924/2006). The prevalent concluding of EFSA reveals that claims have not been established according to regulatory requirements (Salminen \& Loveren, 2012). Still, there is no unified and harmonized legal framework, which would indicate detailed conditions to be complied by a strain to be considered as a probiotic.

The probiotic safety responsible bodies are also the United States Food and Drug Administration (FDA), the UK Joint Health Claims Initiative (JHCI), and Japan Food for Specified Health Use (FOSHU) (Elshaghabee et al., 2017).

\section{BIMODAL BACILLUS sp. AMONG PROBIOTIC BACTERIA}

The globally recognizable group of probiotic bacteria are Lactic Acid Bacteria (LAB), represented by a palette of Lactobacillus species (Joshi \& Singh, 2012) with Lactobacillus acidophilus, L. bulgaricus, L. casei, L. fermentum, L. belveticuslactis, L. plantarum, Bifidobacterium lactis, $B$. breve among others. The LAB species are typically aerotolerant (facultative anaerobic), fermenting, Gram positive, found in and ingested with fermented dairy products like yoghurt, kefir, buttermilk, cheese or fermented vegetables like cabbage or cucumbers. They are known to reside in the human gastrointestinal tract or female genital tract. The forms of application as food supplements are traditionally used lyophilized powders for suspension preparation and encapsulated tablets for oral administration or globules for local application. LABs are able to adhere to gastrointestinal epithelial cells (Castellazzi et al., 2013), thus stabilizing and modulating the inherent gut microbiota, eventually the gut is their primary ecological niche. Other occasionally preferred strains are Bifidobacterium sp., Streptococcus sp. or even a few strains of Enterococcus sp.

The second group of probiotics is referred to as bimodal or allochtonous, and it includes Saccharomyces boulardi, which plays a role in hospital-borne Clostridium difficile contamination of the human GIT and in Escherichia coli (E. coli) infection (Hong et al., 2009). Nevertheless, the group of bimodal probiotics comprises mainly of bacteria belonging to the Bacillus genus of Gram positive, rod-shaped, straight cells, ranging from $0.5-2.5 \times 1.2-10$ $\mu \mathrm{m}$ in size, often arranged in chains. According to Bergey's Manual of Determinative Microbiology (Holt et al., 2000), the strains belonging to the Bacillus genus are chemoorganotrophs, express respiratory or fermentative metabolism, ferment glucose resulting in the production of acid, are positive in the catalase test, and do not reduce sulfates to sulfides. Other biochemical features of the genus, such as nitrate reduction and oxidase production, are variable and dependent on the species.

The Bacillus species share the sporulation ability, forming one oval endospore per cell. This is a crucial feature for Bacillus sp. to survive environmental stress and harsh conditions of growth, preservation, storage and distribution. Spore formers show vast tolerance and survivability in extreme temperatures, $\mathrm{pH}$ (even bile fluids), salt, dehydration or poor nutrition (Holt et al., 2000; JeżewskaFrąckowiak et al., 2017). Despite being aerobic or aerotolerant (facultative anaerobic), Bacillus sp. still can form spores under the air conditions.
The extreme durability of spores is determined by combined factors: the hydrophobic exosporium, consisting of lipids, carbohydrates and proteins; the lowered permeability of cortex- surrounding membrane; the cortex, and the $5-15 \%$ dipicolinic acid content in spore dry weight (Bernardeau et al., 2017). Nutrients, lysozyme and cationic surfactants stimulate the exchange of dipicolinic acid and $\mathrm{Ca}^{2+}$ ions from the spore core for molecules of water, thus allowing the rehydration of enzymes and spore germination.

\section{HUMAN GIT BEING BACILLUS sp. SECOND NATURAL HABITAT}

Bacillus sp. probiotic strains comprise the primary, world-wide microbiota of the human environmental habitat, typically found in soil, water, plants, mammals, aquatic animals, insects and other invertebrates (Hong et al., 2009, Table 2). However, in the modern civilized world of food production on industrial scale, consumption of highly processed food and sophisticated hygienic practices, they may be paradoxically considered as probiotics from "unconventional sources". Bacillus species are also promising and particularly important for an increasingly growing group of lactose-intolerant individuals. They are typically found in non-dairy fermented products, like a variety of traditional fermented foods, for example Japanese natto (fermented soybeans), Korean kimchi (fermented vegetables, mainly cabbage) and Vietnamese fish sauce (Cutting, 2011), as well as in drinks, juices and on raw and unprocessed fruits and vegetables (Sornplang et al., 2016). Bacillus sp. are an alternative to sustain the everyday microbiological balance for human organisms deprived of LAC strain sources.

The bimodal character of Bacillus sp. probiotics is revealed when comparing their content in environmental sites and in the human gastrointestinal tract, which is their second true habitat, as proven with spore content analysis, 16S rRNA gene sequencing and RAPD-PCR fingerprinting of soil and samples obtained from GIT and feces (Hong et al., 2009; Plaza-Diaz et al., 2014; Bernardeau et al., 2017). The life cycle of Bacillus sp. cells in a host organism consists of vegetative cell (VC) divisions, sporulation resulting in spore (SP) formation, germination followed by a metabolic restart called vegetative outgrowth, proliferation and optional resporulation. All these processes, as well as the overall ratio of endospores to vegetative cells in the transit time, greatly depend on the particular Bacillus species, physiological characteristics of the host and the actual location of VCs (for mammals preferably in distal GIT) and SPs (for mammals preferably in upper GIT). The persistence of beneficial Bacillus strains in GIT after their withdrawal from the diet is reported to be up to more than 20 days, as demonstrated in animal studies (Bernardeau et al., 2017).

Concerning the palette of specific and non-specific beneficial mechanisms (Table 3, Table 4) pronounced in an organism, including GIT, UT and UGT, Bacillus sp. strains should be regarded equally as gut commensals, and not exclusively as soil microorganisms.

\section{BENEFICIAL ACTIVITY OF PROBIOTIC ENVIRONMENTAL BACILLUS sp.}

There is a spectrum of essential beneficial features, that allow to include certain Bacillus sp. into probiotic microorganisms category (Table 3 ). These model probi- 
Table 2. Environmental Bacillus spore-formers: selected groups and species, commonly used in probiotic preparations for human and animal use.

\begin{tabular}{ll}
\hline $\begin{array}{l}\text { Genus Bacillus phylogenetic group belonging } \\
\text { species }\end{array}$ & Environmental sources \\
\hline Bacillus subtilis group & soil, water, root of tree, seaweed, larva gut, fermented soybean (natto), kimchi \\
\hline $\begin{array}{l}\text { B. subtilis } \\
\text { soil of Mojave Desert, soil, river mouth, brackish sediment of the river, spacecraft-asso- } \\
\text { ciated clean room class ISO } 8\end{array}$ & $\begin{array}{l}\text { desert soil in Death Valley, soil, waste water, river, sand dunes } \\
\text { B. mojavensis }\end{array}$ \\
$\begin{array}{ll}\text { B. vallismortis } \\
\text { fermented soybean (natto), soil, seaweed, animal feces, camel milk, waste water }\end{array}$ \\
$\begin{array}{l}\text { B. atrophaeus } \\
\text { soil, air, lake water, decomposed wheat, hay dust, yogurt, fish }\end{array}$ \\
$\begin{array}{l}\text { fermented bean curd, sediment and water from hot spring, larva gut, human excre- } \\
\text { fichent }\end{array}$
\end{tabular}

References: Hoa et al., 2000; Lyons \& Kolter, 2017; Wattiau et al., 2001; Elshaghabee et al., 2017; Linhuan, 2013; WFCC GCM 2018

Bacillus pumilus group

$\begin{array}{ll}\begin{array}{l}\text { B. altitudinis } \\ \text { B. pumilus }\end{array} & \text { soil, lake, mangrove, ore mine, insect gut } \\ \text { B. safensis } & \text { soil, leaf, air conditioner filter, larva gut, seaweed fermented fish paste, rice wine } \\ & \begin{array}{l}\text { soil, mangrove water, waste water, river, lake, fermented soybean, molasses waste, } \\ \text { fermented yak milk }\end{array}\end{array}$

References: Lyons \& Kolter, 2017;Elshaghabee et al., 2017; Linhuan, 2013; WFCC GCM 2018

Bacillus cereus group

\begin{tabular}{ll}
\hline B. mycoides & soil, forest soil, water, pond, sludge, leaf, onion and garlic roots \\
B. cereus & $\begin{array}{l}\text { soil, flower, wood core, mangrove sediment, larva gut, market milk, meal remains, pea } \\
\text { soup, javan lori feces }\end{array}$ \\
B. toyonensis & mangrove, soil
\end{tabular}

References: Hoa et al., 2000; Lyons \& Kolter, 2017; Elshaghabee et al., 2017; Linhuan, 2013; Palma et. al., 2014; Jiménez et.al., 2013A,B; WFCC GCM 2018

Bacillus alcalophilus group

B. alcalophilus feces, human feces, distal human intestine, soil, shore line muds

B. gibsonii soil, rice, sediment from salt marshes

B. clausii soil, sediment from salt marshes, clay from grass field,

References: Hoa et al., 2000; Elshaghabee et al., 2017; Linhuan, 2013; Seckbach, 2012, WFCC GCM 2018

otic Bacillus features, particularly safety and survivability of stress within the host, should be assayed with in vitro tests on biochemical models, and in vivo tests, before the implementation of a given strain for common use ( $\mathrm{Pa}-$ padimitriou et al., 2015; Elshaghabee et al., 2017).

Probiotic Bacillus strains, when applied in the form of health foods and dietary supplements or functional feeds and feed supplements, have numerous documented beneficial effects on humans and animals (Table 4). Although the definition of probiotics highly stresses the "living" form of microorganism, represented by a biofilm of Bacillus sp. vegetative cells in the gastrointestinal tract, it is worth noting, that the beneficial qualities are exhibited by the spore forms as well. Biochemical effects induced by the viable Bacillus cells include antimicrobial activity of peptide or large protein bacteriocins (subtilin, ericin S, coagulin or megacin) or antibiotics (bacilysin, surfactin) (Abriouel et al., 2011; Kadaikunnan et al., 2015; Dimkic' et al., 2017; Bernardeau et al., 2017), and the activity of secreted enzymes, aiding the host's digestion of nutritional compounds. Bacillus biofilm formation supports the host organism against GIT, UGT and UT infections, modulating immune system activity (Table 4). The balancing effect and favorable colonization by Bacillus probiotics are sustained even if an administered preparation contains spores (Coppi et. al., 1985), or the sporulation occurs in upper parts of the GIT in the stomach, or due to bile activity. In vitro models of human GIT with B. subtilis, B. clausii, B. pumilus, B. cereus, as well as a recent study on healthy adult human volunteers with Bacillus subtilis (Ghelardi et al., 2015; Bernardeau et al., 2017), revealed germination and outgrowth of spores in the stomach and various gut sections, preferably small intestine. In vitro dynamic multicompartmental TIM1 and TIM2 models stimulating the stomach, small and large intestine (Intestinal Models), showed that even 8\% germination level of Bacillus subtilis provided the sufficient colonization inoculum to decrease Clostridium and Yersinia strains, at the same time increasing the population of various Bifidobacterium species (Hatanaka et al., 2012). 
Table 3. Essential features for model probiotic Bacillus species.

Feature with range of proposed tests

1) Safety (antibiotic resistance ${ }^{1,2}$, production of toxins ${ }^{3}$, genetic stability2; hemolytic activity ${ }^{1,2}$ ).

2) Survivability (survivability in stress conditions e.g. temperature', bile concentration ${ }^{4}, \mathrm{pH}^{4}$, sporulating activity', anaerobic growth').

3) In vivo compatibility (activity towards invertebrates ${ }^{5}$, rodents ${ }^{5}$, mammals ${ }^{5}$ and human studies $\left.2,5,6\right)$.

4) Colonization ability (cell surface hydrophobicity ${ }^{7}$; colonization of intestinal mucosa or feces ${ }^{2,4,6}$ ).

5) Pathogens biocontrol (bacteriocins production 2,3,7, aggregation with pathogens ${ }^{5}$, barrier function of the intestine ${ }^{5,6}$, restoring UT, UGT, GIT microflora 6 ).

6) Immune system interactions (translocation in the gastrointestinal tract (GIT)2,5; anti-inflammatory properties ${ }^{6}$; activating macrophages ${ }^{3}$ ).

7) Stimulation of gene/protein markers production (markers of: stress responses, adhesion $^{5}$, immune system stimulation ${ }^{3}$, nutrients production ${ }^{3}$; enzymes production ${ }^{2,3,7}$ ).

8) Specific medical conditions improvement (blood/ heart diseases 3,5 ,anticancer properties 3,5 ).

${ }^{1}$ Hoa et al., 2000; ${ }^{2}$ Sanders et. al. 2010; ${ }^{3}$ Joshi \& Singh, 2012; ${ }^{4}$ Sornplang et al. 2016; ${ }^{5}$ Papadimitriou et al., 2015; ${ }^{6}$ Reid et. al, 2005; ${ }^{7}$ Kadaikunnan et al., 2015

Table 4. Documented Bacillus sp. probiotics targeted applications with detailed examples of their effects in humans and animals.

\begin{tabular}{|c|c|c|c|c|}
\hline \multicolumn{2}{|c|}{ Targeted application } & \multicolumn{2}{|c|}{ Example } & References \\
\hline \multicolumn{5}{|c|}{ Human products: dietary supplements, health foods } \\
\hline$\checkmark$ & $\begin{array}{l}\text { Food allergy } \\
\text { Intestinal and gastrointestinal } \\
\text { disorders }\end{array}$ & $\begin{array}{l}\checkmark \\
\checkmark \\
\checkmark \\
\checkmark\end{array}$ & $\begin{array}{l}\text { Clinical trials on efficiency and safety of } \\
\text { association with simethicone in patients } \\
\text { with irritable bowel syndrome } \\
\text { Detected ability to affect immunity } \\
\text { and inflammatory genes expression in } \\
\text { GIT and the reduction of inflammatory } \\
\text { diseases of the gut and liver } \\
\text { Vitamin K production } \\
\text { Anti-cancer properties } \\
\text { Restoration of microflora responsible for } \\
\text { the intestinal and systemic immunity }\end{array}$ & $\begin{array}{l}\text { Cutting, 2011; } \\
\text { Joshi \& Singh, 2012; } \\
\text { Castellazzi et al., 2013; } \\
\text { Urgesi et al., 2013; } \\
\text { Plaza-Diaz et al., 2014; Elshaghabee et al., } 2017\end{array}$ \\
\hline$\checkmark$ & $\begin{array}{l}\text { Gastrointestinal infections } \\
\text { Childhood diarrhea }\end{array}$ & $\checkmark$ & $\begin{array}{l}\text { Bacteriotherapy and bacterioprophylax- } \\
\text { is, antimicrobial effect of bacteriocins, } \\
\text { against broad spectrum of microbes } \\
\text { Surface biocontrol components for hos- } \\
\text { pital-dedicated cleaning products } \\
\text { blocking a pathogen's signalling system }\end{array}$ & $\begin{array}{l}\text { Hoa et al., 2000; } \\
\text { Castellazzi et al., 2013; } \\
\text { Vandini et al., 2014; } \\
\text { Kadaikunnan et al., 2015; } \\
\text { Piewngam et al., } 2018\end{array}$ \\
\hline$\checkmark$ & Urinary tract infections & $\checkmark$ & $\begin{array}{l}\text { Reduction of undesired bacteria (Kleb- } \\
\text { siella, Proteus, Shigella, Pseudomonas, } \\
\text { E. coli) in the urine of elderly patients } \\
\text { with slow/static urine flow } \\
\text { Products for topical and oral treatment }\end{array}$ & Meroni et al., 1983; Cutting, 2011 \\
\hline & nal products: feed supplements, fu & tiona & feed & \\
\hline$\checkmark$ & $\begin{array}{l}\text { Pathogens in aquaculture } \\
\text { Gastrointestinal disorders in an- } \\
\text { imals }\end{array}$ & $\checkmark$ & $\begin{array}{l}\text { Veterinary growth promoters and exclu- } \\
\text { sion agents } \\
\text { Biological control agents for aquatic } \\
\text { environments (shrimps, shellfish) } \\
\text { Activity against bacterial infections } \\
\text { (Salmonella enteritidis, pathogenic } E \text {. } \\
\text { coli) in poultry }\end{array}$ & $\begin{array}{l}\text { Verschuere et al., 2000; La Ragione et al., 2001; } \\
\text { La Ragione \& Woodward, 2001; Thirabunyanon } \\
\text { et al., 2011; Olmos \& Paniagua-Michel, 2014; } \\
\text { Yasin et al., } 2016\end{array}$ \\
\hline
\end{tabular}

\section{CONTROVERSIES ON BACILLUS sP. SAFETY}

The variety of Bacillus species share the prevalent common feature of environmental tolerance, as they can be found in a vast range of habitats over the world ( $\mathrm{Ta}$ ble 2), and they are usually bio-safe.
Reliable classifications of probiotic Bacillus species into groups of posed risks towards healthy adults are available from microorganisms' culture collections from the World Federation for Culture Collections (WFCC GCM, 2018): DSMZ, ATCC, NCIB, BCCM/LMG, a.o., see Collection names under the Table 5. Classification into 
Table 5. Examples of probiotic Bacillus sp. type strains with numbers in different microorganism collections and GenBank accession numbers for characteristic sequences.

\begin{tabular}{|c|c|c|c|}
\hline Name of the species & $\begin{array}{l}\text { Type strain numbers } \\
\text { in different collections* }\end{array}$ & $\begin{array}{l}\text { 16S rRNA gene sequence } \\
\text { accession number (bp) }\end{array}$ & $\begin{array}{l}\text { Genome sequence accession } \\
\text { number (bp) }\end{array}$ \\
\hline Bacillus amyloliquefaciens & DSM 7, ATCC 23350 & $\begin{array}{l}\text { AB006920 } \\
(274 \mathrm{bp})\end{array}$ & FN597644 (3980199 bp) \\
\hline Bacillus attrophaeus & $\begin{array}{l}\text { DSM 7264, ATCC49337, NRRL-NRS 2123, } \\
\text { NBRC 15539 }\end{array}$ & $\begin{array}{l}\text { AB } 363731 \\
(1475 \text { bp, partial) }\end{array}$ & $\begin{array}{l}\text { GCA_001591925.1 } \\
(4158197 \text { bp, contig) }\end{array}$ \\
\hline Bacillus cereus & $\begin{array}{l}\text { DSM 31, ATCC14579, CCM 2010, } \\
\text { LMG6923, NCIB 9373, NCTC } 2599\end{array}$ & $\begin{array}{l}\text { AJ841873.1 } \\
\text { (542 bp, partial) }\end{array}$ & $\begin{array}{l}\text { AE016877 } \\
(5411809 \mathrm{bp})\end{array}$ \\
\hline Bacillus coagulans & $\begin{array}{l}\text { DSM1, ATCC 7050, NCIB 9365, NCTC } \\
10334\end{array}$ & $\begin{array}{l}\text { DQ297928 } \\
(1549 \text { bp, partial) }\end{array}$ & $\begin{array}{l}\text { ALAS00000000 } \\
(3018045 \mathrm{bp})\end{array}$ \\
\hline Bacillus pumilus & $\begin{array}{l}\text { DSM 27, ATCC7061, NCIB 9369, NCTC } \\
\text { 10337, CCM } 2144\end{array}$ & $\begin{array}{l}\text { NR_043242 } \\
(1434 \text { bp, partial) }\end{array}$ & $\begin{array}{l}\text { ABRX01000001: } \\
\text { ABRX01000016 } \\
(3833998 \mathrm{bp})\end{array}$ \\
\hline Bacillus safensis & $\begin{array}{l}\text { DSM 19292, ATCC BAA-1126, LMG } \\
26769, \text { NBRC } 100820\end{array}$ & $\begin{array}{l}\text { AF234854 } \\
\text { (1434 bp, partial) }\end{array}$ & $\begin{array}{l}\text { ASJD00000000 } \\
\text { ( } 3731735 \mathrm{bp} \text {, shotgun sequence) }\end{array}$ \\
\hline Bacillus subtilis & $\begin{array}{l}\text { DSM 10, ATCC 6051, CCM 2216, IAM } \\
12118\end{array}$ & $\begin{array}{l}\text { LN681568 } \\
\text { (1502 bp) }\end{array}$ & $\begin{array}{l}\text { CM000488 } \\
(4214598 \mathrm{bp})\end{array}$ \\
\hline Bacillus toyonensis & BCT-7112T, CECT 876T, NCIMB 14858T & $\begin{array}{l}\text { NR_121761 } \\
(1544 \text { bp, partial) }\end{array}$ & $\begin{array}{l}\text { CP006863 } \\
\text { (4940474 bp) }\end{array}$ \\
\hline Bacillus vallismortis & DSM 11031, NRRL B-14890, BCRC17183 & $\begin{array}{l}\text { EF433404 } \\
(1468 \mathrm{bp})\end{array}$ & $\begin{array}{l}\text { AFSH01000070:AFSH01000094 } \\
\text { (series of shotgun sequences) }\end{array}$ \\
\hline
\end{tabular}

*Collection names: ATCC: American Type Culture Collection; BCCM/LMG: Belgian Bacteria Collection; BCRC Bioresource Collection and Research Center (Chinese Taipei); CCM Czech Collection of Microorganisms; CECT Spanish Type Culture Collection; DSMZ: Deutsche Sammlung von Microorganizmen und Zellkulturen (eng. German Collection of Microorganisms and Cell Cultures); IAM Culture Collection (Japan); JCM Japan Collection of Microorganisms; NBRC Culture Collection (Japan); NCIB/NCIMB: National Collection of Industrial Food and Marine Bacteria (UK); NCTC National Collection of Type Cultures (England); NRRL Agricultural Research Service Culture Collection (USA).

Risk group 1 (e.g. in German TRBA, Technical Rules for Biological Agents) is assigned to Prokaryotes that are unlikely to cause an infectious disease in humans, according to the European Directive (2000/54/EC), while a Biosafety level designated as BSL1 (e.g. in American microorganisms collections) refers to the cultures that are not known to harbor an agent that causes disease in healthy adult humans. The cultures that are designated as Risk group 2 or BSL2 present a moderate risk of infection among healthy adults. The numerous strains of $\mathrm{Ba}$ cillus sp. groups shown in Table 2 are described as BSF1 (ATCC) and RG 1 (DSMZ): Bacillus subtilis, B. amyloliquefaciens, B. mojavensis, B. vallismortis, B. atrophaeus, all strains mentioned in the B. pumilus group, B. clausii and B. alcalophilus from the B. alcalophilus group, B. toyonensis from the $B$. cereus group, B. mycoides and B. coagulans, a.o.

However, Bacillus sp. strains are also well known to produce toxins, such as hemolysins, phospholipases, and other enterotoxins. Traditional microbiological plating and biochemical methods for strains characterizations are time-consuming and lack sensitivity or selectivity. Thus, the determination of strains and toxins is performed on B. subtilis, B. pumilus, B. licheniformis, B. poly- myxa, B. thuringiensis and multiple B. cereus strains (ATCC 33018, CA6, CA1, MS1-9, HS23-11) (Gray et al., 2005; Owusu-Kwarteng et al., 2017), using cell cytotoxicity assays, with Ped-2E9-murine hybridoma lymphocytes and CHO-based assays, as well as PCR methods. Hemolysin and lecithinase toxins, emetic toxins, diarrheal toxin, B component (dermonecrotic), EntFM (enterotoxic, induces vascular permeability), CytK (necrotic enteritis) and toxin genes bceT, cytK, nhe A, nheB, nhe C, bblA, bblC, bblD, entFM are typically found in a number of $B$. cereus strains (Gray et al., 2005; Hwang \& Park, 2015).

It is worth mentioning, that available genetic data for B. cereus (whole genome sequence from GenBank, 2018; Table 5) show numerous intrinsic similarities with Bacillus anthracis and Bacillus thuringiensis (Ivanova et al., 2003; Rasko et al., 2005; Palma et al., 2014). B. anthracis and B. weibenstephanesis are examples of pathogenic Bacillus sp., which produce toxins, with different levels of toxicity, posing human or animal-health risk (Riedel, 2005; Żakowska et al., 2012; Elshaghabee et al., 2017; Palma et al., 2014).

Certain severe cases of B. cereus - related food poisoning have been reported (Dierick et al., 2005). A spe-

Table 6. List of European, African and American household chemicals, containing probiotic Bacillus species.

Cosmetics

body spray, body wash, hand soap, skin cream, skin repair concentrate, toothbrush cleaner

Household chemicals

allergen remover spray, baby bottle washing-up liquid, bathroom and toilet cleaner, cleaning concentrate (general purpose), cleaner (general purpose), dish washing-up liquid, drain cleaner, floor cleaner, laundry detergent concentrate, odor and stain remover, septic tank treatment, water system treatment 
cific $B$. cereus strain, detected from human isolates and food remains, caused toxic, severe pulmonary haemorrhage, coma, diffuse bleeding and muscle cramps. Results of PCR amplification, as well as cytotoxicity tests of isolates, confirmed the presence of lecithinase, the beta- hemolytic toxin and heat-stable emetic toxin - cereulide, which was the direct cause of death of poisoning as soon as 13 hours past meal.

Interesting representative of a non-toxigenic and non-pathogenic strain of the $B$. cereus group (Table 2) is B. toyonensis (Bacillus cereus var. toyoi) (Jiménez et al., $2013 \mathrm{~b})$. It is applied in animal nutrition under the name of Toyocerin ${ }^{\circledR}$ probiotic preparation, with no reported cases of toxicity, since its first authorization in Japan, in 1975. B. toyonensis does not produce diarrheal or emetic enterotoxins, thus no enterotoxicity, eye irritation, genotoxicity, acute, subchronic or chronic toxicity were detected at the tested doses, in safety studies including human clinical trials (Williams et al., 2009).

Besides toxin production, antibiotic resistance is a crucial factor to be taken into consideration in the matter of probiotic Bacillus sp. safety (Gueimonde et al., 2013; EFSA Panel on Biological Hazards, 2012). Particularly, the possibility of transferring genes of antibiotic resistance may pose a potential health risk of increasing the presence of antibiotic resistance in bacteria of human/ animal organisms. In this context, mobile, extra-chromosomal elements, such as plasmids with $\operatorname{erm}(\mathrm{C})$ or tet $(\mathrm{L})$ genes, coding for macrolide or tetracycline resistance, respectively, and conjugative transposons Tn5397, carrying genes for tetracycline resistance tet $(\mathrm{M})$, were reported cases in Bacillus subtilis. On the other hand, examples of antibiotic resistance determinants present on the bacterial chromosome, such as aaD2 (aminoglycoside resistance), erm(34) (MLS, macrolides, lincosamides and streptogramines resistance), BCL-1 ( $\beta$-lactams resistance) and cat $(\mathrm{Bcl})$ (chloramphenicol resistance) are found in the Bacillus clausii DSM8716 strain, and used as a probiotic supplement for diarrhoea prevention in humans (Gueimonde et al., 2013).

Nonetheless, it seems that controversies around Bacillus sp. safety are still the crucial factor of their consistently limited application as probiotics.

\section{CHARACTERISTICS OF BACILLUS sp. PROBIOTIC PREPARATIONS}

The probiotic species of the Bacillus genus, based on full length $16 \mathrm{~S}$ rRNA gene sequences, prevalently belong to the subsequent phylogenetic groups (clades): Bacillus subtilis group, Bacillus pumilus group and Bacillus cereus group (Table 2) (Wattiau et al., 2001; Elshaghabee et al., 2017; Lyons \& Kolter, 2017). Bacillus thuringiensis, belonging to the B. cereus group (Miller et al., 2018), is in turn a biotechnological source of parasporal Cry protein (crystal), used as an agricultural biocontrol agent with insecticide activity (Ben-Dov, 2014; Djenane et al., 2017). Other strains, often found in commercial supplements of probiotic preparations for humans or for biotechnology purposes, are B. clausii or B. coagulans.

Commercially available Bacillus sp. probiotic starter cultures and probiotic preparations have diverse microbiological species characteristics. There are numerous reports of applying single species formulations (Hoa et al., 2000; Hong et al., 2005; Cutting, 2011; Olmos \& Paniagua-Michel, 2014; Vandini et al., 2014), with Bacillus subtilis often being preferred due to being the best studied probiotic. Double strain preparations often utilize the composition of Bacillus subtilis with Bacillus from the subtilis group, namely B. mojavensis, B. vallismortis (US origin strains), B. amyloliquefaciens, B. atropheus, B. lichenifromis or from other closely related clades such as: the pumilus group (altitudinis, pumilus, safensis), the cereus group (cereus) or alcalophilus group (clausii). Species are preferably mixed in a 1:1 ratio (Leuschner, 2006; Leuschner, 2008), although the final composition of a preparation may vary after the storage period due to kin discrimination of $B$. subtilis towards very closely related species such as $B$. mojavensis and strains from the pumilus group, and better coexistence with strains from the cereus clade (Lyons \& Kolter, 2017). The mixtures of several strains are named consortiums (Havenaar \& Huis In't Veld, 1992; Hoa et al., 2000; Cutting, 2011; Olmos \& Paniagua-Michel, 2014; Safitri et al., 2015) and may consist of Bacillus subtilis group strains mixed with other closely related group strains, as well as Lactobacillus strains in case of the oral probiotics (Cutting, 2011).

It is worth noting that despite the advanced microbiological techniques used in biotechnological production processes, many commercially available probiotic preparations, even for oral administration in humans, are still being mislabeled or poorly characterized (Hong at al., 2005; Lewis et al., 2016, Jeżewska-Frąckowiak et al., 2017). According to the Bergey's Manual of Determinative Microbiology (Holt et al., 2000), a precise "species differentiation is difficult, because of the large number of representatives and often incomplete descriptions of newly discovered species". The morphology of single colonies of different species on agar media often seems superficially very much alike, making it tricky to differentiate during analytical or diagnostic manipulations (Standards Unit, PHE, 2015; Standards Unit, PHE, 2018). Bacterial colonies of Bacillus sp. may differ more under different growth conditions for one species, than between two different species grown simultaneously in the same conditions. This phenomenon also extends to the shape of single cells observed under the microscope. The conditions of nutrient limitation drive the population of Bacillus subtilis cells to form a mixed population, where half of the population activates the genetic regulator of sporulation and the second half omits this path. Another example of heterogeneity is the coexistence of single swimming cells with an active factor for motility $\left(\sigma^{\mathrm{D}} \mathrm{ON}\right)$, and long chains of cells with motility factor switched off ( $\sigma^{\mathrm{D}}$ OFF) (Kearns \& Losick, 2005). The motility features seem to increase with higher temperatures, where mucoid or slimy colonies appear (Berkeley et al., 2008).

Difficulties in identification result from biochemical features as well, since akin strains of one Bacillus sp. clade, e.g. subtilis or cereus, may barely differ in the composition of fatty acids sustaining their biological membranes (Roberts et al., 1994; Roberts et al., 1996), have highly similar genome architectures, with ANI (average nucleotide identity) values app. below 94\% and display proteome conservation (Earl et al., 2012; Jiménez et al., 2013b).

However, the microbiological identity of probiotic preparation genus/species can be investigated by the unique microbial protein spectrum (proteome) mass spectroscopy analysis in MALDI-TOF assays (Azarko \& Wendt, 2011; Kosikowska et al., 2015), as presented for closely related Bacillus species: Bacillus subtilis, Bacillus mojavensis, Bacillus vallismortis, Bacillus pumilus residing in the same lyophilized preparation sample (Jeżewska-Frąckowiak et al., 2017). Alternatively, a specific determination can be achieved with qualitative PCR reactions, amplifying 
specific genome regions (Table 5) characteristic for either a group of probiotic bacteria (Wattiau et al., 2001) or a single Bacillus species (Ashe et al., 2014). Many species from the Bacillus genus are known to display high similarity in the conserved regions of $16 \mathrm{~S}$ rRNA genes, like Bacillus subtilis and Bacillus pumilus (Berkeley et al., 2008). The highly conserved sequences became a taxonomic marker, not a species marker (Wattiau et al., 2001). It is possible to design PCR primers differentiating between systematic groups of the Bacillus genus, e.g. to distinguish the $B$. subtilis group from $B$. subtilis, $B$. pumilus, $B$. atrophae$u s$, B. licheniformis and B. amyloliquefaciens. An even more specific determination is possible when the unique marker of a strain is determined, like endo- $\beta-1,4$-glucanase of B. subtilis (excluding B. pumilus, licheniformis, amyloliquefaciens, thuringiensis, megaterium). In this case, combining the results of two PCR primer sets leads to an accurate determination of group (genus) and species (Ashe et al., 2014). The PCR reaction products can, of course, also be further cloned and/or sequenced or mapped by the RFLP technique (Restriction Fragments Length Polymorphism), providing even more accurate and precise data. Nevertheless, rapid and reliable identification of Bacillus species is still a challenge due to their very high genome, proteome, and metabolic similarities.

The most thoroughly characterized strains are available under the name of type strains, which according to the International Code of Nomenclature of Prokaryotes (latest version from Parker et al., 2015) are regarded as reference points for any detected strains that could belong to that species. Many probiotic Bacillus species are available in their type strains version, biochemically and genetically characterized, with additional detailed information regarding cultivation conditions, safety, risk groups and a list of references. Examples of probiotic Bacillus sp. type strains, with identity numbers in different microorganism collections and chosen information, covering available genome and 16s rRNA gene nucleotide sequence data with GenBank accession numbers, are given in Table 5 (GenBank, 2018).

\section{INDUSTRIAL FORMS AND STABILIZATION METHODS FOR BACILLUS sp. PROBIOTICS}

The number of possible strain compositions in probiotics reflects the various forms of preparations developed for each intended application. The common industrial forms of Bacillus sp. probiotic preparations are liquid solutions and concentrates or lyophilized powders for resuspension closed in a capsule, vial or pouch.

Traditionally, commercial starter cultures of probiotics and ready-to-use probiotic microbiological preparations are supplied in a liquid form (solution or concentrate) that can be used directly for the purpose, e.g. B. coagulans in suspensions (Hu et al., 2016), or as a microbiological starter in food production, biological control agent, the component of a biodegrading mixture, or surfactant. The liquid cultures, such as Bacillus sp. starter culture, when dedicated for pharmaceutical use in humans or animals, can be further concentrated or preferably also stabilized (Kringelum et al., 2000), similar to what was described for B. coagulans, B. licheniformis, B. pumilus and B. subtilis for future food infusion (Kirejevas \& Kazarjan, 2012). An example of a stabilizing solution for Bacillus, but also Lactobacilli and Bifdobacteria, is vegetable (sunflower seed, olive, maize, soya, lineseed, sesame, rice) or animal (fish) oil with the addition of polysaccharides, such as maltodextrin or inulin (Mantzouridou et al., 2012).
The necessity for long-term storage of probiotic preparations, the need for increased stability, as well as transport requirements come along with convenience of use and optimization of the probiotic delivery. These are the crucial considerations and reasons for developing solid form probiotics cultures preservation technologies. The Bacillus probiotic spore formers are perfect model microorganisms surviving stabilization methods that generate powder products, like freeze-drying (lyophilization) or drying, which both involve cell dehydration (Goderska, 2012; Martín et al., 2015). The present trends in probiotic delivery cover a whole palette of microencapsulation methods, which can significantly increase cell viability during freezing or drying processes (Both et al., 2012; Chávarri et al., 2012; Martín et al., 2015). The inner core of the microcapsule is composed of the bacterium cell or cells and the shell is sustained by a supporting material. Popular supporting materials used in microencapsulation extrusion techniques include alginate solutions (algae derived heteropolysaccharides), whey proteins, pectin, milk or human-like collagen (Chávarri et al., 2012; Martín et al., 2015). A probiotic B. coagulans strain was successfully encapsulated using polysaccharides, chitosan and alginate (Anselmo et al., 2016), while the extracellular matrix produced by $B$. subtilis is proposed to serve as a protectant for other probiotic bacteria in complex preparation (Yahav et al., 2018). The addition of cryo-protectants such as glucose, maltodextrin, trehalose, skimmed milk powder, whey protein or novel soybean flour additionally increases the survival rates and the activity of intracellular enzymes of the freeze-dried encapsulation probiotics, as demonstrated for $B$. subtilis starter cultures or LAB (Martín et al., 2015, Mahidsanan et al., 2017).

\section{FUTURE TRENDS FOR PROBIOTIC BACILLUS sp. IN MANAGING HAZARDOUS BIOFILMS}

Probiotic use in humans is still widely associated with orally administered supplements, with an increasing range of Bacillus sp. preparations exemplified by Bacticubtyl ${ }^{\circledR}(B$. cereus, France, Germany), Bibactyl ${ }^{\circledR}$ (B. subtilis, Vietnam),

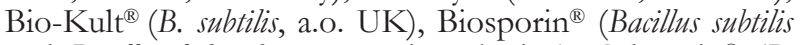
and Bacillus licheniformis, Russia, Ukraine), Calsporin ${ }^{\circledR}$ (B. subtilis, Japan), Enterogermina ${ }^{\circledR}$ (B. clausii, Italy), and Primal Defense ${ }^{\circledR}$ (B. subtilis, a.o., USA).

The promising present and future application of probiotic Bacillus sp. seems to be the biocontrol strategy for managing the microflora of the human body and human's closest environment - the modern household. Specific conditions of kitchen and bathroom facilities make them reservoirs of unwanted microbiota biofilms, with Salmonella sp., Listeria sp., E. coli and Staphylococcus sp. (Giaouris et al., 2015), as well as numerous fungal species like Exophiala sp., Fusarium sp., Aspergillus sp. or Candida strains (Zupančič et al., 2016), algae and protozoa. Hazardous biofilms may have contact with prepared food or be directly transmitted onto the human body, causing a health risk. Cleaning or disinfection products seem to have only minor or transitory effects in long term perspective, as microbial communities gradually develop resistance to antimicrobial agents (Mah \& O’Toole, 2001; Myszka \& Czaczyk, 2007), while the persistent use of disinfectants may deteriorate human microflora.

In this context, recent evidence for probiotic Bacillus sp. ability to block pathogens' signaling system of quorum sensing-managed colonization (Piewngam et al., 2018; Pérez-Gutiérrez et al., 2013; Noorashikin et al., 2016 ) is of the highest importance. The ability of Staph- 
ylococcus aureus ( $S$. aureus) to increase population density, thus causing the infection, has been successfully inhibited with the key role of Bacillus sp. fengycins, a class of lipopeptides, previously known to damage fungus cell membrane (Piewngam et al., 2018).

Moreover, the advantage of using spore forming probiotic Bacillus sp. is their compatibility with chemical formulations used for household chemistry. The repeatable, regular application of products containing probiotic Bacillus species promotes their colonization and proliferation on vulnerable surfaces (Banaszczyk et al., 2017), thus assuring microbiological balance. Chemical products containing probiotic species of Bacillus sp. may have various physical forms, including paste, atomized spray, liquid under pressure or solution. Examples of household chemicals available on European, African and US markets are presented in Table 6. Microbiological analyses indicate, that widely applied species are B. subtilis, $B$. licheniformis and B. pumilus (authors' unpublished data), however the information provided by manufacturers is rather scarce, usually omitting exact names of supplemented bacterial species and details concerning whether the formulation contains single or multiple bacterial strains.

Screening for novel, beneficial environmental strains with probiotic qualities within the Bacillus genus seems to be a promising future trend to develop new probiotic preparations. New Bacillus sp. strains have been recently characterized, showing inhibition against mycotoxigenic fungi aflatoxins (Veras et al., 2016) or causing decolonization of methicillin resistant $S$. aureus (Bacillus strain TSH58, Chauhan et al., 2017).

\section{CONCLUSION}

The natural environmental microflora of non-pathogenic Bacillus species can become a present remedy for many contemporary issues related to human health and well-being after the civilization lifestyle changes that have dramatically altered our habitat and its microbiological population.

\section{Acknowledgements}

The authors would like to thank Marta Skowron-Volponi and Patrick Groves for critical reading of the manuscript and English corrections.

\section{Acknowledgements of Financial Support}

This work was supported by GRUPA INCO S.A., ul. Wspólna 25, 00-519 Warsaw, Poland, NCBiR grant POIG.01.04.00-02-181/13 and Polish Ministry of Science and Higher Education funds DS 530-8645-D746-18 available for University of Gdansk, Faculty of Chemistry, Department of Molecular Biotechnology.

\section{REFERENCES}

2000/54/EC Directive of the European Parliament and Council of 18.09.2000 on the protection of workers from risks related to exposure to biological agents at work. Official Journal of the European Communities No. L 262/21 of 17.10 .2000

Abreo A, Gebretsadik T, Stone CA, Hartert TV (2018) The impact of modifiable risk factor reduction on childhood asthma development. Clin Transl Med 7: 15. http://doi: 10.1186/s40169-018-0195-4

Abriouel H, Franz ChMAP, Ben Omar N, Gálvez A (2011) Diversity and applications of Bacillus bacteriocins. FEMS Microbiol Rev 35(1): 201-232. https://doi.org/10.1111/j.1574-6976.2010.00244.x
Anselmo A C, McHugh K J, Webster J, Langer R, Jaklenec A (2016) Layer-by-layer encapsulation of probiotics for delivery to the microbiome. Adv Mater 28: 9486-9490. doi: 10.1002/adma.201603270

Araya M, Gopal P, Lindgren SE, Lodi R, Oliver G, Saxelin ML, Servin AL, Stanton C, Gilliland SE, Morelli L, Reid G, Pineiro M, Schlundt J (2001) Joint FAO/WHO Expert Consultation on Evaluation of Health and Nutritional Properties of Probiotics in Food including Powder Milk with Live Lactic Acid Bacteria. In Probiotics in food. Health and Nutritional properties and guidelines for evaluation, FAO Food and Nutrition paper 85. http://www.fao.org/3/a-a0512e.pdf

Ashe S, Maji UJ, Sen R, Mohanty S, Maiti NK (2014) Specific oligonucleotide primers for detection of endoglucanase positive Bacillus subtilis by PCR. 3 Biotech 4: 461-465. http://doi:10.1007/s13205013-0177-6

Azarko J, Wendt U (2011) Identification of microorganisms - comparison of biochemical and mass spectrometry method. Diagn Lab 47: 409-417

Banaszczyk J, Jędrzejczak G, Zarzeczańska D, Ramotowska S, Fiutak M, Skowron M, Ossowski T, Skowron P, Jeżewska-Frąckowiak J (2017) Probiotic Bacillus sp. environmental strains as a component of improved dishwasher cleaning product. W Sci News 72: 141-149

Ben-Dov E (2014) Bacillus thuringiensis subsp. israelensis and its dipteran-specific toxins. Toxins 6: 1222-1243. http://doi:10.3390/toxins6041222

Berkeley RM, Heyndrickx NL, De Vos P (2008) Applications and systematics of Bacillus and relatives. Wiley-Blackwell. Oxford

Bernardeau M, Lehtinen MJ, Forssten SD, Nurminen P (2017) Importance of the gastrointestinal life cycle of Bacillus for probiotic functionality. J Food Sci Technol 54: 2570-2584. doi: 10.1007/s13197-0172688-3

Björkstén B, Naaber P, Sepp E, Mikelsaar M (1999) The intestinal microflora in allergic Estonian and Swedish 2-year-old children. Clin Exp Allergy 29(3): 342-346. erratum in Clin Exp Allergy 30: 1047. https://doi.org/10.1046/j.1365-2222.1999.00560.x

Björkstén B. (1994) Risk factors in early childhood for the development of atopic diseases. Allergy 49: 400-407. https://doi. org/10.1111/j.1398-9995.1994.tb00831.x

Bloomfield SF, Stanwell-Smith R, Crevel RWR, Pickup J (2006) Too clean, or not too clean: the Hygiene Hypothesis and home hygiene. Clin Exp Allergy 36: 402-425. http://doi: 10.1111/j.13652222.2006.02463.x

Both E, Gyenge L, Bodor Z, Gyorgy E, Lanyi S, Abraham B (2012) Intensification of probiotic microorganisms viability by microencapsulation using ultrasonic atomizer. UPB Buletin Scientific Series B: Chem Mater Sc 74: 27-32

Castellazzi AM, Valsecchi C, Caimmi S, Licari A, Marseglia A, Leoni MC, Caimmi D, del Giudice MM, Leonardi S, La Rosa M, Marseglia GL (2013) Probiotics and food allergy. Ital J Pediatr 39: 47. http://doi: 10.1186/1824-7288-39-47

Chauhan AK, Maheshwari D K, Bajpai V K (2017) Isolation and preliminary characterization of a bacteriocin-producer Bacillus strain inhibiting methicillin resistant Staphylococcus aureus. Acta Biol Hung 68: 208-219. doi: 10.1556/018.68.2017.2.8

Chávarri M, Marañón I, Villarán MC (2012) Encapsulation Technology to Protect Probiotic Bacteria. In Probiotics. Ch23 pp 501-540. InTech, Rijeka, Rigobelo. http://dx.doi.org/10.5772/50046

Coppi F, Ruoppolo M, Mandressi A, Bellorofonte C, Gonnella G, Trinchieri A (1985) Results of treatment with Bacillus subtilis spores (Enterogermina) after antibiotic therapy in 95 patients with infection calculosis. Chemioterapia 4: 467-470

Cutting SM (2011) Bacillus probiotics. Food Microbiol 28: 214-220. http://doi: 10.1016/j.fm.2010.03.007

Dierick K, Van Coillie E, Swiecicka I, Meyfroidt G, Devlieger H, Meulemans A, Hoedemaekers G, Fourie L, Heyndrickx M, Mahillon J (2005) Fatal family outbreak of Bacillus cereus-associated food poisoning. J Clin Microbiol 43: 4277-4279. doi: 10.1128/JCM.43.8.42774279.2005

Dimkic' I, Stankovic' S, Nišavic' M, Petkovic' M, Ristivojevic' P, Fira D, Beric' T (2017) The profile and antimicrobial activity of Bacillus lipopeptide extracts of five potential biocontrol strains. Front Microbiol 8: 925. https://doi.org/10.3389/fmicb.2017.00925

Djenane Z, Nateche F, Amziane M, Gomis-Cebolla J, El-Aichar F, Khorf H, Ferré J (2017) Assessment of the antimicrobial activity and the entomocidal potential of Bacillus thuringiensis isolates from Algeria. Vernon L. Tesh ed. Toxins 9: 139. http://doi:10.3390/toxins9040139

Earl AM, Eppinger M, Fricke WF, Rosovitz MJ, Rasko DA, Daugherty S, Losick R, Kolter R, Ravel J (2012) Whole-genome sequences of Bacillus subtilis and close relatives. J Bacteriol 194: 2378-2379. http:// dx.doi.org/10.1128/JB.05675-11

EC No 1924/2006 Regulation of the European Parliament and of the Council of 20 December 2006 on nutrition and health claims made on foods. Official Journal of the European Union

EFSA Panel on Biological Hazards (2012) Scientific opinion on the maintenance of the list of QPS biological agents intentionally add- 
ed to food and feed (2012 update). EFS A J 10: 3020. doi:10 3020 10.2903/j.efsa.2011.2497

Elshaghabee FMF, Rokana N, Gulhane RD, Sharma C, Panwar H (2017) Bacillus as potential probiotics: status, concerns, and future perspectives. Front Microbiol 8: 1490. http://doi:10.3389/ fmicb.2017.01490

Emese B, László G, Zsolt B, György É, Szabolcs Lanyi, Ábrahám B (2012) Intensification of probiotic microorganisms viability by microencapsulation using ultrasonic atomizer. UPB Scientific Bulletin, Series B: Chemistry and Materials Science. 74

GenBank (2018) https://www.ncbi.nlm.nih.gov/genbank/

Ghelardi E, Celandroni F, Salvetti S, Gueye SA, Lupetti A, Senesi S (2015) Survival and persistence of Bacillus clausii in the human gastrointestinal tract following oral administration as spore-based probiotic formulation. I Appl Microbiol 119: 552-559. doi: 10.1111/ jam. 12848

Giaouris E, Heir E, Desvaux M, Hébraud M, Møretrø T, Langsrud S, Doulgeraki A, Nychas G-J, Kacániová M, Czaczyk K, Ölmez H, Simões M (2015) Intra- and inter-species interactions within biofilms of important foodborne bacterial pathogens. Front Microbiol 6: 841. http://doi: 10.3389/fmicb. 2015.00841

Goderska K (2012) Different methods of probiotics stabilization. In Probiotics. Ch24 pp 541-550. InTech, Rijeka, Rigobelo. http:// dx.doi.org/10.5772/50313

Gray KM, Banada PP, O’Neal E, Bhunia AK (2005) Rapid Ped-2E9 cell-based cytotoxicity analysis and genotyping of Bacillus species. J Clin Microbiol 43: 5865-5872. doi: 10.1128/JCM.43.12.58655872.2005

Gueimonde M, Sánchez B, G de Los Reyes-Gavilán C, Margolles A (2013) Antibiotic resistance in probiotic bacteria. Front Microbiol 4. doi: $10.3389 /$ fmicb.2013.00202

Hatanaka M, Nakamura Y, Maathuis AJ, Venema K, Murota I, Yamamoto N (2012) Influence of Bacillus subtilis C-3102 on microbiota in a dynamic in vitro model of the gastrointestinal tract simulating human conditions. Benef Microbes 3: 229-236. doi: 10.3920/ BM2012.0016

Havenaar R, Huis In't Veld JHJ (1992) Probiotics: a general view. In The Lactic Acid Bacteria in Health and Disease. Elsevier Science Publishers, pp 151-170. London and New York

Hoa NT, Baccigalupi L, Huxham A, Smertenko A, Van PH, Ammendola S, Ricca E, Cutting SM (2000) Characterization of Bacillus species used for oral bacteriotherapy and bacterioprophylaxis of gastrointestinal disorders. Appl Environ Microbiol 66: 5241-5247. PMCID: PMC92451

Holt JG, Krieg NR, Sneath PHA, Staley J, Williams ST (2000) Bergey's Manual of Determinative Microbiology, 9th edn, Lippincott Williams\&Wilkins, Philadelphia

Hong HA, Duc Le H, Cutting SM (2005) The use of bacterial spore formers as probiotics, FEMS Microbiol Rev 29: 813-835. https://doi. org/10.1016/j.femsre.2004.12.001

Hong HA, Khaneja R, Tam NMK, Cazzato A, Tan S, Urdaci M, Brisson A, Gasbarrini A, Barnes A, Cutting SM (2009) Bacillus subtilis isolated from the human gastrointestinal tract. Res Microbiol 160: 134-143. http://doi: 10.1016/j.resmic.2008.11.002

Hu Y, Liu Y, Yang W, Liu Y, Zhang Y, Yin J (2016) Preparation method for Bacillus coagulans bacterial suspension. Nanjing Tech University, WO/2016/150152

Hwang JY, Park JH (2015) Characteristics of enterotoxin distribution, hemolysis, lecithinase, and starch hydrolysis of Bacillus cereus isolated from infant formulas and ready-to-eat foods. J Dairy Sci 98: 16521660. doi: $10.3168 /$ jds.2014-9042

Ivanova N, Sorokin A, Anderson I, Galleron N, Candelon B, Kapatral V, Bhattacharyya A, Reznik G, Mikhailova N, Lapidus A, Chu L, Mazur M, Goltsman E, Larsen N, D’Souza M, Walunas T, Grechkin Y, Pusch G, Haselkorn R, Fonstein M, Ehrlich SD, Overbeek R, Kyrpides N (2003) Genome sequence of Bacillus cereus and comparative analysis with Bacillus anthracis. Nature 423: 87-91. doi: 10.1038 / nature 01582

Jeżewska-Frąckowiak J, Seroczynska K, Banaszczyk J, Wozniak D, Skowron M, Ozog A, Żylicz-Stachula A, Ossowski T, Skowron P (2017) Detection of endospore producing Bacillus species from commercial probiotics and their preliminary microbiological characterization. J Environ Biol 38: 1435-1440. http://doi: 10.22438/ jeb/38/6/MRN-478

Jiménez G, Blanch AR, Tamames J, Rosselló-Mora R (2013A) Complete genome sequence of Bacillus toyonensis BCT-7112T, the active ingredient of the feed additive preparation Toyocerin. Genome Announc 1: e01080-13. doi: 10.1128/genomeA.01080-13

Jiménez $G$, Urdiain M, Cifuentes A, López-López A, Blanch AR, Tamames J, Kämpfer P, Kolsto AB, Ramón D, Martínez JF, Codoner FM, Rosselló-Móra R (2013B) Description of Bacillus toyonensis sp. nov., a novel species of the Bacillus cereus group, and pairwise genome comparisons of the species of the group by means of ANI calculations. Syst Appl Microbiol 36: 383-391. https://doi. org/10.1016/j.syapm.2013.04.008
Joshi VK, Singh RS (2012) Food Biotechnology. Principles and practices. IK International Publishing House Pvt. Ltd, New Delhi

Kadaikunnan S, Rejiniemon TS, Khaled JM, Alharbi NS, Mothana R (2015) In-vitro antibacterial, antifungal, antioxidant and functional properties of Bacillus amyloliquefaciens Ann Clin Microbiol Antimicrob 14: 9. https://doi.org/10.1186/s12941-015-0069-1

Kearns DB, Losick R. (2005) Cell population heterogeneity during growth of Bacillus subtilis. Genes Dev 19: 3083-3094. http:// doi:10.1101/gad.1373905

Kirejevas V, Kazarjan A (2012) Probiotic oil suspension and use thereof. BACTERFIELD Gmbh, WO/2010/122107A1; EP2421384A1

Kosikowska U, Stępień-Pyśniak D, Pietras-Ożga D, Andrzejczuk S, Juda M, Malm A (2015) Application of MALDI-TOF MS for identification of clinical isolates of bacteria from humans and animals. Diagn Lab 51: 23-30

Kringelum B, Kringel M, Nielsen KS (2000) Method for supply of starter cultures having a consistent quality. Chr.Hansen A/S, WO2001070935A2

La Ragione RM, Casula G, Cutting SM, Woodward MJ (2001) Bacillus subtilis spores competitively exclude Escherichia coli O78:K80 in poultry. Vet Microbiol 79: 133-142. https://doi.org/10.1016/S03781135(00) $00350-3$

La Ragione RM, Woodward MJ (2001) Competitive exclusion by Bacillus subtilis spores of Salmonella enterica serotype Enteritidis and Clostridium perfringens in young chickens. Vet Microbiol 94: 245-256. https:// doi.org/10.1016/S0378-1135(03)00077-4

Leuschner R (2006) CRL, Evaluation report on the analytical methods submitted in connection with Section II, 2.5, (Control Methods) of the Application for authorisation as a feed additive according to Regulation (EC) No 1831/2003, BioPlus 2B (for turkeys for fattening), Active agents: Bacillus subtilis DSM 5750, Bacillus licheniformis, DSM 5749, European Comission Joint Research Centre, Institute for Reference Materials and Measurements, Community Reference Laboratory, Feed Additives Authorisation D08-FSQ(2006)D/15068

Leuschner R (2008) CRL Evaluation report on the analytical methods submitted in connection with Section II, 2.5 (Control Methods) of the Application for authorisation as a Feed Additive according to Regulation (EC) No $1831 / 2003$, BioPlus $2 \mathrm{~B}^{\circledR}$ for rabbits, Active Agent(s): Bacillus subtilis DSM 5750 and Bacillus licheniformis DSM 5749, European Comission Joint Research Centre, Institute for Reference Materials and Measurements, Community Reference Laboratory, Feed Additives Authorisation D08/FSQ/CVH/RL/D(2008)16171

Lewis ZT, Shani G, Masarweh CF, Popovic M, Frese SA, Sela DA, Underwood MA, Mills DA (2016) Validating bifidobacterial species and subspecies identity in commercial probiotic products. Pediatr Res 79: 445-452. http://doi:10.1038/pr.2015.244

Linhuan W (2013) Global catalogue of microorganisms (gcm): a comprehensive database and information retrieval, analysis, and visualization system for microbial resources. BMC Genomics 14. doi: 10.1186/1471-2164-14-933

Lyons NA, Kolter R (2017) Bacillus subtilis protects public goods by extending kin discrimination to closely related species. MBio 8 pii: e00723-17. doi: 10.1128/mBio.00723-17

Mah TF, O’Toole GA (2001) Mechanism of biofilm resistance to antimicrobial agents. Trends Microbiol 9: 34-39. https://doi.org/10.1016/ S0966-842X $(00) 01913-2$

Mahidsanan T, Gasaluck P, Eumkeb G (2017) A novel soybean flour as a cryoprotectant in freeze-dried Bacillus subtilis SB-MYP-1. LWT Food Science and Technology 77: 152-159. https://doi.org/10.1016/j. lwt.2016.11.015

Mantzouridou F, Spanou A, Kiosseoglou V (2012) An inulin-based dressing emulsion as a potential probiotic food carrier. Food Res Int 46: 260-269. https://doi.org/10.1016/j.foodres.2011.12.016

Martín MJ, Lara-Villoslada F, Ruiz MA, Morales ME (2015) Microencapsulation of bacteria: A review of different technologies and their impact on the probiotic effects. Innov Food Sci Emerg Technol 27: 1525. https://doi.org/10.1016/j.ifset.2014.09.010

Meroni PL, Palmieri R, Barcellini W, De Bartolo G, Zanussi C (1983) Effect of long term-treatment with $B$. subtilis on the frequency of urinary tract infections in older patients. Chemiotherapia 2: 142-144

Metchnikoff E (1907) Prolongation of life. Optimistic studies. Paris, Eng transl. Mitchell PC, 1908, GP Putnam's Sons, New York and London, The Knickerbocker Press

Miller RA, Jian J, Beno SM, Wiedmann M, Kovac J (2018) Intraclade variability in toxin production and cytotoxicity of Bacillus cereus group type strains and dairy-associated isolates. Appl Environ Microbiol 84: e02479-17. http://doi:10.1128/AEM.02479-17

Myszka K., Czaczyk K. (2007) Mechanisms determining bacterial biofilm resistance to antimicrobial factors. Biotechnology 1: 40-52

Noorashikin MN, Li LY, Karim M, Daud HM, Natrah FMI (2016) Screening and identification of quorum sensing degraders from live feed Artemia. J Environ Biol 37: 811-816. PMID: 28779741

Olmos J, Paniagua-Michel J (2014) Bacillus subtilis A potential probiotic bacterium to formulate functional feeds for aquaculture. $J$ Microb Biochem Technol 6: 361-365. http://doi: 10.4172/1948-5948.1000169

Owusu-Kwarteng J, Wuni A, Akabanda F, Tano-Debrah K, Jespersen L (2017) Prevalence, virulence factor genes and antibiotic resistance 
of Bacillus cereus sensu lato isolated from dairy farms and traditional dairy products. BMC Microbiol 17: 65. doi: 10.1186/s12866-0170975-9

Palma L, Muñoz D, Berry C, Murillo J, Caballero P (2014) Bacillus thuringiensis toxins: an overview of their biocidal activity. Toxins $\mathbf{6}$ : 3296-3325. doi: 10.3390/toxins6123296

Papadimitriou K, Zoumpopoulou G, Foligné B, Alexandraki V, Kazou M, Pot B, Tsakalidou E (2015) Discovering probiotic microorganisms: in vitro, in vivo, genetic and omics approaches. Front Microbiol 6: 58. http://doi: 10.3389/fmicb.2015.00058

Parker C, Tindall B, Garrity G (2015) International Code of Nomenclature of Prokaryotes. Int J Syst Evol Microbiol IJSEM-D-1500747R1. doi: 10.1099/ijsem.0.000778

Pérez-Gutiérrez R-A, López-Ramírez V, Islas Á, Alcaraz LD, Hernández-González I, Olivera BC, Santillán M, Eguiarte LE, Souza V, Travisano M, Olmedo-Alvarez G (2013) Antagonism influences assembly of a Bacillus guild in a local community and is depicted as a food-chain network. ISME J 7: 487-497. doi: 10.1038/ismej.2012.119

Piewngam P, Zheng Y, Nguyen TH, Dickey SW, Joo HS, Villaruz AE, Glose KA, Fisher EL, Hunt RL, Li B, Chiou J, Pharkjaksu S, Khongthong S, Cheung GYC, Kiratisin P, Otto M (2018) Pathogen elimination by probiotic Bacillus via signalling interference. Nature 562: 532-537. doi: 10.1038/s41586-018-0616-y

Plaza-Diaz J, Gomez-Llorente C, Fontana L, Gil A (2014) Modulation of immunity and inflammatory gene expression in the gut, in inflammatory diseases of the gut and in the liver by probiotics. World J Gastroenterol 20: 15632-15649. http://doi: 10.3748/wjg.v20. i42.15632

Quigley EMM (2010) Prebiotics and probiotics; modifying and mining the microbiota. Pharmacol Res 61: 213-218. http://doi: 10.1016/j. phrs.2010.01.004

Rasko DA, Altherr MR, Han CS, Ravel J (2005) Genomics of the Bacillus cereus group of organisms. FEMS Microbiol Rev 29: 303-329. doi: $10.1016 /$ i.femsre.2004.12.005

Ravel J, Blaser MJ, Braun J, Brown E, Bushman FD, Chang EB, Davies J, Dewey KG, Dinan T, Dominguez-Bello M, Erdman SE, Finlay BB, Garrett WS, Huffnagle GB, Huttenhower C, Jansson J, Jeffery IB, Jobin C, Khoruts A, Kong HH, Lampe JW, Ley RE, Littman DR, Mazmanian SK, Mills DA, Neish AS, Petrof E, Relman DA, Rhodes R, Turnbaugh PJ, Young WB, Knight R, White O (2014) Human microbiome science: vision for the future. Microbiome 2: 16. http://doi.org/10.1186/2049-2618-2-16

Reid G, Hammond JA (2005) Probiotics: Some evidence of their effectiveness. Can Fam Physician 51: 1487-1493. PMCID: PMC1479479

Riedel S (2005) Anthrax: a continuing concern in the era of bioterrorism. Proc (Bayl Univ Med Cent) 18: 234-243. PMID: 16200179

Roberts MS, Nakamura LK, Cohan FM (1994) Bacillus mojavensis sp. nov., distinguishable from Bacillus subtilis by sexual isolation, divergence in DNA sequence, and differences in fatty acid composition. Int J Syst Bacteriol 44: 256-264

Roberts MS, Nakamura LK, Cohan FM (1996) Bacillus vallismortis sp. nov., a close relative of Bacillus subtilis, isolated from soil in Death Valley, California. Int J Syst Bacteriol 46: 470-475

Safitri R, Priadie B, Miranti M, Astuti AW (2015) Ability of bacterial consortium: Bacillus coagulans, Bacilus licheniformis, Bacillus pumilus, Bacillus subtilis, Nitrosomonas sp. and Pseudomonas putida in bioremediation of waste water in Cisirung waste water treatment plant. Agro Life Si J 4: 146-152

Salminen S, van Loveren H (2012) Probiotics and prebiotics: health claim substantiation. Microb Ecol Health Dis 23 . http://doi. org/10.3402/mehd.v23i0.18568

Sanders ME, Akkermans LM, Haller D, Hammerman C, Heimbach J, Hörmannsperger G, Huys G, Levy DD, Lutgendorff F, Mack D, Phothirath P, Solano-Aguilar G, Vaughan E (2010) Safety assessment of probiotics for human use. Gut Microbes 1: 164-185. http:// doi: $10.4161 /$ gmic.1.3.12127

Schnorr SL, Sankaranarayanan K, Lewis CM, Warinner C (2016) Insights into human evolution from ancient and contemporary microbiome studies. Curr Opin Genet Dev 41: 14-26. https://doi. org/10.1016/j.gde.2016.07.003
Seckbach J (2012) Life in Extreme Habitats and Astrobiology. In: Journey to Diverse Microbial Worlds: Adaptation to Exotic Environments. Springer Science \& Business Media, pp 410. ISBN 9401142696, 9789401142694

Sornplang P, Piyadeatsoontorn S (2016) Probiotic isolates from unconventional sources: a review. J Anim Sci Technol 58: 26. http:// doi:10.1186/s40781-016-0108-2

Standards Unit, PHE, Microbiology Services, Public Health England, UK (2015) Standards for microbiology investigations. Identification of Bacillus species. In Bacteriology - Identification 9: 1-27

Standards Unit, PHE, Microbiology Services, Public Health England, UK (2018) Standards for microbiology investigations. Identification of Bacillus species. In Bacteriology - Identification 9: 1-27

Strachan DP (1989) Hay fever, hygiene and household size. B M J 299: 1259-1260. PMCID: PMC1838109

Thirabunyanon M, Thongwittaya N (2011) Protection activity of a novel probiotic strain of Bacillus subtilis against Salmonella enteritidis infection. Res Vet Sci 93: 74-81. https://doi.org/10.1016/j. rvsc.2011.08.008

Turnbaugh PJ, Ley RE, Hamady M, Fraser-Liggett C, Knight R, Gordon JI (2007) The human microbiome project: exploring the microbial part of ourselves in a changing world. Nature 449: 804-810. https:/ /doi:10.1038/nature06244

Urgesi R, Casale C, Pistelli R, Rapaccini GL, de Vitis I (2013) A randomized double-blind placebo-controlled clinical trial on efficacy and safety of association of simethicone and Bacillus coagulans (Colinox $^{(2)}$ in patients with irritable bowel syndrome. Eur Rev Med Pharmacol Sci 18: 1344-1353

Vandini A, Temmerman R, Frabetti A, Caselli E, Antonioli P, Balboni PG, Platano D, Branchini D, Mazzacane S (2014) Hard surface biocontrol in hospitals using microbial-based cleaning products. PLoS ONE 9: e108598. http://doi:10.1371/journal.pone.0108598

Veras FF, Correa AP, Welke JE, Brandelli A (2016) Inhibition of mycotoxin-producing fungi by Bacillus strains isolated from fish intestines. Int J Food Microbiol 238: 23-32. doi: 10.1016/j.ijfoodmicro.2016.08.035

Verschuere L, Rombaut G, Sorgeloos P, Verstraete W (2000) Probiotic bacteria as biological control agents in aquaculture. Microbiol Mol Biol Rev 64: 655-671. PMCID: PMC99008

Waligora-Dupriet AJ, Butel MJ (2012). Microbiota and allergy: Dysbiosis to probiotics. In Allergic Diseases - Highlights in the Clinic, Mechanisms and Treatment. http://doi: 10.5772/26234

Wattiau P, Renard M-E, Ledent P, Debois V, Blackman G, Agathos S (2001) A PCR test to identify Bacillus subtilis and closely related species and its application to the monitoring of wastewater biotreatment. Appl Microbiol Biotechnol 56: 816. https://doi.org/10.1007/ s002530100691

West CE, Dzidic M, Prescott SL, Jenmalm MC (2017) Bugging allergy; role of pre-, pro- and synbiotics in allergy prevention. Allergol Int 66: 529-538. http://doi: 10.1016/j.alit.2017.08.001

WFCC GCM (2018) World Federation of Culture Collections, Global Catalogue of Microorganisms. http://gcm.wfcc.info/

Williams LD, Burdock GA, Jiménez G, Castillo M (2009) Literature review on the safety of Toyocerin, a non-toxigenic and non-pathogenic Bacillus cereus var. toyoi preparation. Regul Toxicol Pharmacol 55: 236-246. doi: 10.1016/j.yrtph.2009.07.009

Yahav S, Berkovich Z, Ostrov I, Reifen R, Shemesh M (2018) Encapsulation of beneficial probiotic bacteria in extracellular matrix from biofilm-forming Bacillus subtilis. Artif Cells Nanomed Biotechnol 27: 1-9. doi: 10.1080/21691401.2018.1476373

Yasin IM, Razak NF, Natrah FMI, Harmin SA (2016) Selection and evaluation of Malaysian Bacillus spp. strains as potential probiotics in cultured tiger grouper (Epinephelus fuscoguttatus). J Environ Biol 37: 791-800. PMID: 28779739

Żakowska D, Bartoszcze M, Niemcewicz M, Bielawska-Drózd A, Kocik J (2012) New aspects of the infection mechanisms of B. anthracis. Ann Agric Environ Med 19: 613-618

Zupančič J, Novak Babič M, Zalar P, Gunde-Cimerman N (2016) The black yeast Exophiala dermatitidis and other selected opportunistic human fungal pathogens spread from dishwashers to kitchens. PLoS ONE 11: e0148166. doi: 10.1371/journal.pone.0148166 